Горан М. Максимовић ${ }^{1}$

Универзитет у Нишу

УДК 821.163.41.09-94 Краков С.

Филозофски факултет

Одсек за србистику

https://doi.org/10.46630/ish.7.2021.10

\title{
ПРИКАЗ ВЕЛИКОГ РАТА \\ У КЫИЗИ ЖИВОТ ЧОВЕКА НА БАЛКАНУ \\ СТАНИСЛАВА КРАКОВА
}

У реферату је анализиран приказ Великог рата (1914-1918) у мемоарској књизи Живот човека на Балкану, књижевника Станислава Кракова (1895-1968), коју је написао највјероватније између 1936 . и 1968. године, а објављена је из рукописне заоставштине три деценије након његове смрти, тек 1997. године. Краков је непосредно као борац на фронту учествовао у три рата, Првом и Другом балканском и Великом рату, при чему је три пута тешко рањаван и више пута одликован за јунаштво. Предмет наше посебне анализе представља приказ догађаја из Првог свјетског рата. Односи се то прије свега на мобилизацију и ратне операције 1914. године, а затим и на повлачење српске војске крајем 1915. и почетком 1916. године преко Црне Горе и Албаније, све до грчког острва Крфа. Најпотпунију слику ратних операција Краков је изложио у записима са „Солунског фронта” (1916-1918), као и у приказу ратних операција за ослобођење читаве земље до краја 1918. године. Ради се о једној од најузбудљивијих књига српске документарно-умјетничке прозе написане у 20. вијеку, у којој се на креативан начин жанровски укрштају особине аутобиографско-мемоарске и романескне прозе.

Кључне ријечи: Велики рат, Албанија, Крф, Солунски фронт, аутобиографија, мемоари, роман, прича.

1.0.Књижевник Станислав Краков (1895-1968) као борац учествовао је у три рата, Првом и Другом балканском рату, као и у Великом или Првом свјетском рату. Други свјетски рат и трагичне године окупације Србије провео је у Београду, све до августа 1944. када је отишао у егзил у Аустрију и Швајцарску, гдје је остао све до смрти 1968. Није онда нимало случајно што је човјек такве животне путање, а несумњивог књижевног дара и историјске самосвијести, оставио једно од најаутентичнијих аутобиографско-мемоарских дјела српске књижевности, са рјечитим насловом Живот човека на Балкану, које је први пут из рукописне заоставштине објављено 1997. Према досадашњим сазнањима, рукопис је настајао много раније, а највјероватније између 1936. и 1968.

\footnotetext{
${ }^{1}$ goran.maksimovic@filfak.ni.ac.rs
} 
Рукопис је сачињен из двије неједнаке цјелине. У првој и најпотпунијој цјелини, насловљеној „Кроз ратове”, у средишту пажње налазе се предратне, ратне и непосредне поратне године (1895-1912-1918-1920), од дана рођења у породици коју су чинили отац Пољак и мајка Српкиња из гласовите породице Недић, гимназијског школовања у Београду, добровољног учешћа у два балканска рата, па све до учешћа у Великом рату, када се показао као изразито храбар ратник, више пута рањаван и одликован (Максимовић, 2021: 647-648). У другом, започетом и недовршеном дијелу рукописа, насловљеном „Кроз Аустрију”, записи су усмјерени на средину 1945. када се са породицом налазио у избјеглиштву у аустријским Алпима и када је био изложен потјерама титоистичких гонитеља који су тражили његово изручење да би му се судило због оптужбе да је био „сарадник окупатора”. „О свом емигрантском животу, написао је свега три поглавља о првим годинама у Аустрији, која су једна врста трагичног епилога Живота човека на Балкану" (Арсенијевић-Краков, 2019: 7). Рукопис је остао недовршен, а у том облику је објављен, како смо претходни истакли, тек 1997. Таква херојска и трагична историјска судбина Станислава Кракова, у којој је био „национални херој Првог”, а затим „издајник Другог светског рата” (Стојић, 2019: 349-350), представља парадигму за разумијевање судбине читавог српског народа у 20. вијеку.

2.0.Приказ Великог рата Краков започиње сјећањем на очеве завјетне ријечи које му је поручио на самрти да је „част једног човека нешто што стоји изнад живота”, те да убије онога ко му дирне у част: „Част је нешто што се брани крвљу” (Краков, 2019: 28). Када све то имамо у виду, а поготово чињеницу да је и по очевом пољском и по мајчином српском поријеклу био потомак неустрашивих побуњеника и бораца за слободу, онда не чуди што се још као гимназијалац, седмог разреда пријавио у добровољце и учествовао у Првом балканском рату 1912.

Управо од другог поглавља „Кроз артиљеријску ватру” започињу ратни записи Станислава Кракова. Упркос томе што су записи о Првом балканском рату 1912. важни, наша превасходна пажња усмјерена је на приказ Великог рата. Након што је у мају 1914. завршио прву годину војне академије као „други у класи”, већ у јуну је са друговима послат у Скопље на љетњу фортификацијску обуку у Скопској Црној Гори. Краков наглашава да тада нико од њих није ни слутио да више никада неће ступити у своју Војну академију. Најприје је његова генерација питомаца-каплара премјештена средином јула у Крагујевац, а затим су добили различите распореде на свим фронтовима. Краков је са још двојицом другова распоређен у Пожаревац на „Дунавски фронт” за ађутанта једног батаљона другопозиваца. Захваљујући томе упознао је браћу Рибникар, Владислава и Дарка, новинаре и власнике 
листа Политика, а командант батаљона био му је Радослав Петковић, рођени брат пјесника Владислава Петковића Диса. Краков наглашава да се тада спријатељио са Владиславом Рибникаром и да му је он једном приликом саопштио пророчанску истину: „Ви сте, Краков, војник, али за рат. Нећете Ви остати у војсци у миру. То не одговара Вашем темпераменту. Ви сте рођени за новинара" (Краков, 2019: 64). Тада је Краков имао прилику и да непосредно упозна пјесника Диса, који је дошао у посјету код брата официра, да се непосредно дружи са њим и да остави лијепе записе о његовој личности. Краков наглашава да му је Дис тада рекао: „Ето, зато волим рат, јер овде смрт није хладна ни мрачна, већ долази у апотеози” (Краков, 2019: 67).

Убрзо иза тога Краков је прекомандован у Пирот, а овај дио својих ратних успомена, које попримају форму вијенца кратких „ратних цртица”, окончава ријечима да више никада није видио ниједног од својих нових пријатеља, јер су браћа Рибникар погинула петнаестак дана касније у биткама на Дрини, а Дис се утопио у водама Јонског мора, недалеко од Крфа, приликом повратка из Француске на броду који су торпедовале њемачке подморнице 1917. године. Читава класа Станислава Кракова је у октобру 1914. док је он још био у Пироту, произведена у чин потпоручника. Наглашава да је био незадовољан што није био у непосредним борбама на Церу и Колубари, те да је у више наврата тражио прекоманду и одлазак на „Дринско ратиште”. Премјештен је у 17. пешадијски пук почетком децембра и ова једница ће бити нераздвојно везана за његову даљу ратну судбину. Наглашава да се добро сјећао колико се његов отац плашио тог броја, јер је вјеровао да постоји фатална веза између његове судбине и броја „17”, али да је он тада „радосно ишао у тај пук”. Међутим, пошто се јавио у нову јединицу, која је била стационирана на Мишару, баш у вријеме окончања Колубарске битке и велике побједе српске војске, Краков није имао прилику да непосредно учествује у великим ратним операцијама 1914.

2.1. Када су започеле нове ратне операције у септембру 1915. Краков нас извјештава да је његов пук пребачен у Сурдулицу и на Власину, као појачање за одбрану од предстојеће бугарске офанзиве. Може се рећи да тада започињу најузбудљивије странице пишчевих сјећања. Краков описује како је одмах по доласку добио задатак да са својом групом од 12 војника запосједне караулу Букова Глава на Власини, а затим је након бугарског напада у ноћи између 2. и 3. октобра, његова јединица пребачена на Криву Феју, гдје ће се одиграти једна од најтежих борби у којима је учествовао. Са много упечатљивих детаља приказује то опште ратно лудило и како у човјеку „уместо страха да не буде убијен, избија страшно пијанство: убијати...” (Краков, 2019: 98). У једном од тих јуначких јуриша Кракова је преко груди пресјекао рафал, али је био рањен само у лијеву руку, јер му је новчаник који се налазио на грудима испред срца зауставио оловну куглу, која би га 
сигурно усмртила. Након превијања наставио је да се бори, а у том „вртлогу уништавања” и сам је осјетио „потребу да убија”. Сјећао се беспоштедних јуриша са обје стране, продора уз планинске косе и узмицања пред артиљеријом противника. Запамтио је како је пушчаним хицем пресјекао покрет једног бугарског војника. На крају овога „дана славе”, када су успјели да зауставе бугарски продор на српску земљу и када се његова јединица повукла у Предејане, командант му је саопштио да ће га предложити, уз још једног рањеног потпоручника, за унапређење у чин поручника и за одликовање. Краков је тек тада примијетио да је на његовој униформи било четрнаест улазних и излазних рана: „Сад тек примећујем да су ми не само блуза, већ и чакшире и доколенице све избушене мецима. Пребројавам четрнаест улазних и излазних рана на униформи. Захватио ме је цео сноп из митраљеза и ипак само једну једину рану добио. У буђелару ми је метак исекао на комаде две банкноте од по сто динара, а изнад саме главе пресекао моју прву фотографију у официрској униформи. Други метак ми је скоро додирнуо трбух, пробивши и блузу и чакшире” (Краков, 2019: 104).

Међутим, тада су стигли и трагични гласови да је Врање пало у бугарске руке и да је пресјечена жељезничка пруга према Скопљу и Солуну. Краков казује и о узалудним надама да ће из Солуна стићи у помоћ француске и енглеске трупе које би са Галипоља требало да пређу у Вардарску и Моравску долину. Због високе температуре коју је добио након рањавања Краков је послат у велику „Нишку болницу” гдје је провео пет дана на опоравку, а допуст је искористио да оде у Јагодину и посјети мајку која се ту налазила у избјеглиштву, са женом и дјецом свога брата, пуковника Милана Недића. Након четири дана боравка у Јагодини, која је провео у „атмосфери свога детињства", док се у даљини све снажније чула тутњава тешке артиљерије, Краков се вратио у јединицу на Власини, која је тада била стационирана на планини Чемерник. Напомиње да је породици док је био у Јагодини стигла вијест да је његов најмлађи ујак резервни капетан Божидар Недић био тешко рањен, да се налазио у болници у Крушевцу, због чега је његова мајка отишла хитно да посјети рањеног брата.

2.2.Након тога су услиједили описи тешких борби и сталног повлачења српске војске, али и општег страха који се био увукао у тамошњи народ. Краков са болом описује како су их у Грделици дочекале истакнуте бијеле крпе на кућама, јер уплашени становници нису знали гдје да се склоне и једино им је преостало да тако покушају да умилостиве бугарске јединице. Краков наглашава да је тада „први пут осетио понижење побеђеног” (Краков, 2019: 115). Долином Ветернице, под сталним борбама, повлачила се српска војска према Косову, а при томе су се непрестано као „чопор курјака” пробијали из обруча. У једној од тих борби погођен је у главу коњ на коме је јахао. У том страшном расулу и безнађу читаве једне државе коју је на- 
пало више непријатеља, на територији Косова су их мучки ударале групице Арбанаса, али су упркос свему 1. новембра стигли у Приштину. Краков у тим суморним сликама издваја потресни сусрет са калуђерима из Студенице који су спасавали мошти Стефана Првовјенчаног. „Наше су ноге биле тешке од залепљеног црвеног косовског блата. Наши су шињели били тешки, натопљени непрестаном кишом. Али су најтежа била наша срца" (Краков, 2019: 120).

Појавиле су се гласине да ће српска војска на Косову извести „одсудну битку" и покушати да направи контраудар на аустријске и бугарске трупе, али је убрзо и та најмања трунка наде угасла јер је стигла команда да крећу у одступање све до Јадранског мора. Најприје су стигли до Пећи и Метохије, која је тада била у границама Црне Горе, а затим су преко Руговске клисуре и Чакора кренули према Плаву и Гусињу. Краков се тада тешко разболио од исцрпљености и глади тако да су помисли да је добио срдобољу, а сумњали су и на колеру. У једном тренутку су чак помислили и да је преминуо. Међутим, све је издржао и некако се опоравио захваљујући можда и томе што су се зауставили у Плаву. Краков описује како су због несташице хране и глади били принуђени да експлозивом лове рибе у језеру. На обалама Плавског језера су предахнули неколико недеља, али је тада наступио дефетизам међу војницима који су хтјели да се враћају кући, да напусте јединице и дезертирају, јер су сматрали да их заклетва не обавезује изван „граница отаџбине”. Преко шест стотина војника је нестало тих дана и покушало да се врати кућама, а заправо је отишло у сигурну смрт или заробљеништво. Краков тада својим војницима држи патетичан говор и на крају им поручује да ,заклетва не зна за границе, као ни отаџбина, јер је она у нама, у нашим срцима" (Краков, 2019: 123).

2.3.Повлачење према Подгорици, дијела српске војске у којој се налазила и јединица Станислава Кракова изведено је преко непроходних и уских стаза планине Ком, испод којих се налазио стрмоглави кланац ријеке Цијевне. „Црногорци зову баш овај део Кома, одакле извире Цијевна, Проклетија планина. Одиста је ово ноћ проклетства" (Краков, 2019: 153). Гладни, промрзли и изнурени, четврто јутро су стигли у Подгорицу, средином децембра, али их је и ту сачекала велика несташица хране и глад, тако да су већ сутрадан били принуђени да наставе марш према Скадру. Краков убједљиво и са много натуралистичко-веристичких детаља свједочи о страдању и надљудским напорима пробијања кроз мочварне стазе на обалама Скадарског језера, о застрашујућој глади, умирању војника, очајању и безнађу. Чинило му се да људи више нису били у стању да примјећују тај „прелаз између живота и смрти” и било је довољно само да се на тренутак зауставе да предахну и да заувијек остану на том несрећном мјесту. У једном тренутку су прелазили преко правог „моста мртваца” и стотинама ме- 
тара газили преко мртвих тијела погинулих другова који су заувијек остали у том блату.

Долазак у околину Скадра свима је повратио изгубљену наду, а Краков је са поносом избројао све људе из свога вода. „Изгледали су као авети, али су сви били на броју" (Краков, 2019: 158). Краков нас извјештава да је у Скадру била смјештена и „Српска влада” са Николом Пашићем, који је био пун наде и увјерења да је „најгоре прошло”, а тада су сазнали и да чекају савезничке бродове који би требало да их одвезу за Крф и Бизерту. На крају нас извјештава да је његов пук 25. јануара 1916. године укрцан на велики француски пароброд „Вердон” који их је послије тешке ноћне пловидбе по узбурканом Јадранском мору донио на обале Крфа.

Готово двомјесечни боравак свога пука на острву Крфу, Краков описује на различите начине. Најприје нас извјештава о страшним умирањима исцрпљених и болесних српских војника који су били смјештени у болницу на сусједном острву Видо. Подсјећа нас да је о том страдању и сахрањивању умрлих у Јонском мору, српски пјесник Бојић, написао пјесму „Плава гробница”. Са друге, стране Краков говори и о нормализацији живота, о обнављању и новом устројавању јединица српске војске. Без зазора и прикривања говори и о љубавним авантурама, а посебно о својим сталним сусретима, љубавним и еротским уживањима, са младом дјевојком Маријом у граду Крфу. Као посебно важно искуство на Крфу наводи чињеницу да је у штабу Дринске дивизије упознао Драгутина Димитријевића Аписа, који је тада био постављен за начелника дивизијског штаба. Краков је био импресиониран личношћу вође „Црне руке”, а поготово је био срећан што га је Апис примио са много присности јер су му саопштили да се ради о сестрићу потпуковника Милутина Недића, који је и сам био члан Аписове тајне официрске организације. На крају разговора Апис му је поручио: „Буди као што су твоји ујаци" (Краков, 2019: 174). Почетком априла 1916. јединица Станислава Кракова је након „четвородневне пловидбе око Грчке” премјештена на Халкидики, што је био поуздан знак да се приближавају нове борбе и одлазак на „Солунски фронт”.

3.0.Можемо казати да „солунске године” у даљим запамћењима Станислава Кракова представљају посебну аутобиографско-мемоарску цјелину. Смјењиваће се и прожимати у тим записима херојске и бруталне слике са „солунског ратишта” са приказима распусног цивилног живота у Солуну, који су упознавали приликом ријетких долазака у град на одмор и лијечење.

3.1.Тренуци насладе по солунским борделима били су краткотрајни, а ратна страдања на фронту и казивање о томе константни. Краков нас извјештава да је његова јединица крајем јула отишла на Могленске планине, 
а да су прве борбе започеле већ седмог августа 1916. Упечатљиво описује нове ратне доживљаје и наглашава да га је „поново обузело лудо пијанство простора, битке која почиње, игре са смрћу и стрмоглаве јурњаве кроз грмљавину и црне облаке експлозија" (Краков, 2019: 182). Његов батаљон је добио задатак да освоји ,редут на Горничеву”, а када су кренули у јуриш развила се битка прса у прса. Тада је један бугарски метак погодио камен испред Кракова тако да су бројни опиљци засули његове очи и на тренутак га заслијепили. Тек што се опоравио у једном од каснијих јуриша, Краков описује како га је детонација гранате бацила у бугарски ров, а непријатељски војник га је почео давити. Спасила га је „лудачка присебност” тако што је дограбио своју каму и два пута је сјурио у врат свога давитеља све док га није заклао. Видјећемо касније да је та сцена оставила дубоке ожиљке у Краковљевој психи и да му се често у сновима јављала као ноћна мора. Краков при томе не пише да је заклао Бугарина или непријатеља, већ обичног човјека и војника. „Тренутак када осети како се нож зарива у туђе тело мења Краковљеву перцепцију борбе и рата уопште и тада то тело губи атрибуте непријатеља и постаје човек, што убиству даје још већу тежину. Пред њим лежи не непријатељ, не Бугарин, не злочинац који је пре само неколико тренутака желео да га удави онако како само онај који мрзи може да дави, већ човек" (Захаријевић, 2017: 117). У тим страшним борбама које су трајале данима и ноћима „сваки четврти војник” из Краковљевог батаљона је погинуо, а рањенима се није знао број. Краков са пуно пажње приказује најразличитије детаље из тих крвавих борби, као што описује рањавања и страдања бројних својих сабораца. Запамћења се у тим дијеловима преображавају у читав вијенац кратких „ратних прича”, својеврсних „цртица” чији су главни јунаци његови ратни другови.

Битка за освајање коте 2525 , посљедње тачке на планини Кајмакчалан, започела је 4. септембра. Краков наглашава да је у свијести свих његових сабораца одзвањала наредба која је стигла из Врховне команде: „Ви сте на капији своје земље, на вама је да отворите врата своје отаџбине” (Краков, 2019: 203). У том крвавом пробоју, приликом једног јуриша, Краков је био рањен у ногу, тако да су морали одмах у привременој болници да му изваде метак, што су и урадили без анестезије. Краков је тек касније у болници сазнао да је Кајмакчалан пао и да је баш његов 17. пук заузео највишу коту овог граничног планинског виса. О каснијим догађајима на Кајмакчалану Краков нас извјештава посредно на основу вијести које су са фронта стизале у солунску француску ратну болницу „Принцеза Марија”. Планина је непрестано „прелазила из руку у руке”, а колико су борбе биле жестоке најбоље говори чињеница да су ровови двије војске били удаљени свега десетак метара једни од других. Захваљујући томе Бугари су 13. септембра били опет повратили коту 2525 тако што су по ноћи упали у наше ровове и бајонетима уништили читав други батаљон. Напокон је Кајмакчалан пао 
17. септембра и српска војска је поново ступила на тло своје „поробљене отаџбине". Краков нас смирено и попут неког историографа извјештава да је цијена била огромна јер је више од тридесет хиљада српских војника погинуло или рањено у том пробоју.

3.2.Краков приказује и своје болничке дане у Солуну. Описује како му се у сновима као ноћна мора јављао лик онога бугарског војника са Горничевског виса, кога је заклао бајонетом. Краков нас извјештава да су билтени са фронта свакодневно доносили вијести о побједама српске и француске војске, једино се „Енглези нису мицали са Дојрана”. Највећу радост је свима донијела побједничка вијест од 6. новембра 1916. да је српска војска ослободила Битољ. Наглашава да му је ујак, Милан Недић, предлагао да иде у Француску и да тамо обучава „ђачку чету” из које су планирали да изведу нову генерацију резервних официра. Краков је то одбио и без размишљања му саопштио: „Ја се враћам на фронт, јер су тамо моји војници, моји другови и пријатељи, којих је сваког дана све мање, и јер сам тамо на свом, слободном, тлу. Ја сам тамо потпуно срећан, јер знам да је тамо моје место". Када му је ујак казао да ће као официр морати извршити наређење ако га буде добио, Краков му је без размишљања казао: „Или се могу убити” (Краков, 2019: 221). Ујак га је загрлио и пољубио у оба образа након тога и саопштио му да је и он сам затражио да га пошаљу на фронт.

3.3.Одмах по повратку у јединицу, Краков је сазнао двије вијести. Прва је била тужна и говорила је о томе да се био потпуно „истопио” 1. батаљон 17. пука, јер су готово сви војници и официри страдали или су били рањени, због чега је овај славни пук морао бити расформиран. Краков приказује тај тренутак на драматичан начин и саопштава нам да је тада написао и једну патетичну пјесму „Опроштај са 17. пуком”. Вјерује да је пјесма била слаба, али је била аутентични одјек узбуђења и очајања свих оних малобројних преживјелих војника тог пука. Друга вијест је била лијепа и говорила је о одликовањима која је добио у борбама приликом пробоја Кајмакчалана, биле су ту армијске и дивизијске похвале, а највреднији је био „Бели орао са мачевима IV реда".

Краков наглашава да је након повратка на фронт наступило затишје због огромних губитака које су преживјели и Срби и Бугари. „Епопеја јуриша и подвига је већ давно завршена и сада је остала још једино неугледна и неславна смрт у блату" (Краков, 2019: 227). Тада је донио одлуку да почне да се „сећа и пише” и то да напише роман о 1915. Краков износи и занимљив поетички став о томе шта је за њега романескно писање: „Роман је увек фиктивни или реални живот, а најчешће је аутобиографија” (Краков, 2019: 227). На основу тих назнака познато нам је да је тада започет и највећим дијелом написан први пишчев роман Кроз буру који је објављен 1921. Тада 
је покренуо и шаљиви рукописни лист „Рововац”, који је био радо читан не само у његовом батаљону него и међу војницима осталих јединица. Познато је да су у децембру 1916. изашла четири броја листа и да је обустављена његова израда онда када је објављена Краковљева репортажа о замишљеном „протестном митингу коња и магарца на фронту”, јер је штаб дивизије оцијенио да такви написи штете угледу јединице и читаве српске војске. Претпоставља се да је лист „добио назив према омиљеном артиљеријском оруђу, које су српски војници од миља звали 'рововац' (топ сличан минобацачу) и често користили у рововским борбама тог времена, јуришима и контрајуришима" (Јовановић, 2014: 981).

Међутим, поред свих тих епизода, ипак је у Краковљевим сјећањима из прве половине 1917. средишње мјесто заузео један крупан историјски догађај. Хапшење пуковника Драгутина Димитријевића Аписа, под оптужбом да је припремао „,атентат на регента”, а затим и суђење познато под именом „Солунског процеса”. Апис је тада са неколико својих најближих сарадника „црнорукаца”, мајором Вуловићем и наводним атентатором Малобабићем, осуђен на смрт и стријељан у јуну 1917. То је оставило веома ружан укупан утисак на читаву српску војску, а поготово на велику већину официра и подофицира, јер су отворено сумњали у истинитост те оптужбе, а искрено су вољели овог храброг човјека и побуњеника. Краков нас извјештава да је сазнао од свог ујака Милана Недића да је био одређен са судију у „Солунском процесу”, али да је одбио да учествује у томе, послије чега је одмах из команде у Солуну послат на фронт. Можемо казати да се у овим сегментима Краковљева аутобиографско-мемоарска запамћења приближавају историографској студији.

Читаво 14. поглавље запамћења „Паскал на рововској коси”, Краков је посветио портретисању необичне личности, свога блиског рођака по мајци и пријатеља, Димитрија Љотића. При томе наглашава колико је била нестална личност његовог рођака и колико је био подложан различим врстама утицаја и учења, а да при томе није имао имао изграђен сопствени поглед на свијет.

Краков описује и једну необичну епизоду на фронту када је увесељавао своје другове казивањима о младој француској играчици Денизет коју је упознао у Солуну. Сви су се веселили тим ласцивним сликама, а само је Љотић захтијевао да прекине са причањем и још му је руком покушао да запуши уста. Краков га је тада у афекту снажно ударио песницом у вилицу и готово нокаутирао. Љотић му то није узео за зло, пољубио га је и након тога су постали „најбољи пријатељи”. Заједно су захваљујући самом чуду или некој вишој промисли избјегли и сигурну смрт у рову, јер су непосредно прије пада једне бугарске гранате на њихову земуницу били напустили то мјесто и тако се спасили. У каснијем пробоју „Солунског фронта”, Љотић је показао неустрашивост и примјерну храброст, а тешко је био рањен у руку у борбама за ослобођење Велеса. 
3.4.У поглављу „Последњи јуриш”, Краков приказује судбоносне септембарске дане 1918. када је напокон започела велика савезничка операција пробоја „Солунског фронта” и коначног ослобођења Србије. Краков наглашава да је ратна активност његовог новог 5. пешадијског пука, започела 16. септембра 1918. на Градешничкој коси, а све даље је била „славна епопеја”, јер је тада Краков непосредно са својом јединицом освојио ту важну стратешку коту. Заробљено је више од 800 бугарских војника и тиме је практично започет дефинитивни слом „бугарског фронта”. Краков признаје да је то био „најлепши моменат” у његовом „седмогодишњем ратовању” (Краков, 2019: 261). У даљим наступањима Краковљева јединица је као претходница пробијала бугарске линије одбране и незадрживо напредовала кроз Пелагонију и читаву Македонију. При томе, описује и неке невјероватне детаље, када је био на граници смрти, као приликом грешке његовог поднаредника Љубомира који је случајно активирао бомбу која му је била у џепу, а онда се „одузео од страха” и није знао да је одбаци од себе. Невјероватном присебношћу Краков је у посљедњем тренутку узео ту бомбу и бацио је тако да је експлодирала на свега неколико метара од њих двојице. Захваљујући томе преживјели су и остали непровријеђени.

Краков са поносом наглашава да је лично предводио групу војника која је продрла у Велес и ослободила овај важни стратешки град на Вардару. У том сегменту запамћења створене су праве мале прозне минијатуре, што је у складу са Краковљевим циљем да од заборава сачува бројне анонимне јунаке и страдалнике. Краков са неизмјерним поносом записује и податак да је тада пред камером шефа кинематографске секције фанцуске армије дао изјаву као српски војник који је први ушао у ослобођени Велес. Тај запис је остао у трајној архиви француске армије, а Краков га је десетак година касније пронашао и уврстио у свој документарни филм „За част отаџбине”, који је био приказан 1930. Колико је у тим ратним операцијама занос и одушевљење српских војника било снажно најбоље казују Краковљеве ријече: „Ми више не трчимо, ми летимо, јер нам се чини да је смрт ту, на површини полуделе земље, а не и у ваздуху" (Краков, 2019: 269).

Краков описује да је на висовима код Криве Паланке дочекао историјски датум, 12. октобар 1918. када је капитулирала „Бугарска армија”, а био је непосредни свједок разоружавања читаве те поражене и понижене, а у годинама окупације веома крволочне војске. Наглашава да су на десетинама заробљених топова видјели грб са двоглавим српским орлом што је био знак да је то оно исто наоружање које су Срби морали да оставе приликом повлачења у јесен 1915. Након тога је Краковљева јединица наступала великом брзином и улазила у Врање, Лесковац, Прокупље. Посебно је пажљиво описао долазак у разорено и уништено Прокупље, гдје су још увијек били уочљиви призори угушеног Топличког устанка из прољећа 1917. године, као и трагови страшних бугарских злочина који су услиједили као одмазда 
над цивилима након гушења устанка. Људи су овдје заборавили да се смију, нико није имао снаге да се радује, били су опустошени, побијени и застрашени. „У читавом овом крају сви бунари су заједничке гробнице” (Краков, 2019: 285). Познато је да је Краков, поводом обиљежавања десет година од Топличког устанка, у марту и априлу 1927. године, у листу Време, објавио серију новинских текстова у којима је дао исцрпнији поглед на овај велики војнички догађај, али и огромну трагедију коју је преживио српски народ у топличком крају под бугарском окупацијом у Великом рату (Станојловић, 2019: 349-354).

Са много више одушевљења дочекао их је народ у ослобођеном Крушевцу и Крагујевцу. Посебно је Крагујевац пробудио најсентименталније Краковљеве успомене, јер је то био његов родни град, а још више од тога било је то „место сусрета и љубави” његовог оца и мајке. У каснијим записима Краков наглашава да је његова једница 14. новембра 1918. избила у Шабац и да је имао част да буде ,први српски официр који је ступио на територију Аустро-Угарске, доносећи слободу" (Краков, 2019: 296). Тада је у Руми упознао искрене српске родољубе, попут др Жарка Миладиновића, који га је дочекао у име формираног „Народног већа” српског Срема, а управо тих дана је до Кракова стигла вијест и да је добио за јунаштво показано на Кривој Феји (у јесен 1915) „Златну медаљу Обилића за храброст”.

6.0.Укратко закључујемо да приказ Великог рата у књизи Живот човека на Балкану Станислава Кракова садржи прворазредна свједочења. Зато је поред аутобиографско-мемоарске књиге можемо читати и као вијенац „кратких прича” о људима и догађајима из ратова. Поједине дијелове ове књиге можемо читати и као кратке „психолошке студије”, попут казивања о личности Димитрија Љотића, али и о феномену страха и јунаштва, о танкој граници између живота и смрти. Могуће је у овој књизи пратити и документарно-умјетничке путеве преображавања запамћења у праве мале „историографске студије”, попут записа о „Солунском процесу” 1917. и стријељању Драгутина Димитријевића Аписа. Све то заједно учинило је да приказ Великог рата у књизи Живот човека на Балкану прерасте у истинску сазнајну авантуру и умјетничко искуство.

\section{Литература}

Арсенијевић-Краков, 2019. Милица Арсенијевић Краков, „Сећање на оца”, предг. у књизи Станислав Краков, Живот човека на Балкану, Логос-Наш дом, Београд, с. 7-12.

Захаријевић, 2017. Душан Захаријевић, „Живот човека на Балкану Станислава 
Кракова", Липар, год. XVIII, број 62, Крагујевац, с. 113-124.

Јовановић, 2014. Наташа Јовановић, „Рововац (1916): рукописни лист Станислава Кракова", Књижевна историја, год. 46, број 154, Београд, с. 979-992.

Краков, 2019. Станислав Краков, Живот човека на Балкану, Логос-Наш дом, Београд.

Максимовић, 2021. Горан Максимовић, „Рат и прича у књизи Живот човека на Балкану Станислава Кракова”, пог. у књизи: Станислав Краков, Живот човека на Балкану, прир. Горан Максимовић, Дела Станислава Кракова, Документарно-мемоарска дела, свеска 1, Службени гласник-Универ. библиотека „Светозар Марковић”, Београд, с. 647-692.

Станојловић, 2019. Нинослав Станојловић, „Топлички устанак у новинским текстовима и белешкама Станислава Кракова", Топлички зборник, часопис за друштвено-хуманистичке науке, год. IV, број 4, Прокупље, с. 349-354.

Стојић, 2019. Биљана Стојић, „Станислав Краков у ратовима за ослобођење и уједињење (1912-1918)”, Историјски часопис, књ. LXVIII (2019), с. 349-382.

Goran M. Maksimovic

\section{THE GREAT WAR IN STANISLAV KRAKOV'S BOOK THE LIFE OF A MAN IN THE BALKANS}

\section{Summary}

The paper analyzes the review of the Great War (1914-1918) in the memoir book The Life of a Man in the Balkans, by the writer Stanislav Krakov (1895-1968), which he wrote most probably between 1936 and 1968, and was published from a manuscript legacy three decades later after his death, in 1997. Krakov directly participated as a participant at the front in three wars, the First and Second Balkan Wars and the Great War, during which he was severely wounded three times and awarded several times for heroism. The subject of our special analysis is a review of events from the First World War. This refers primarily to the mobilization and war operations in 1914, and then to the withdrawal of the serbian army at the end of 1915 and the beginning of 1916 through Montenegro and Albania, all the way to the Greek island of Corfu. Krakov presented the most complete picture of the war operations in the records from the Salonica Front (1916-1918), as well as in the review of the war operations for the liberation of the entire country until the end of 1918. It is one of the most exciting books of Serbian documentary-artistic prose written in the 20th century, in which the features of autobiographical-memoir and novel prose intersect in a creative way.

Key words: Great War, Albania, Corfu, Salonica Front, autobiography, memoirs, novel, story. 